\title{
Application of pyrolysis process in processing of mixed food wastes
}

\author{
Barbora Grycová, Ivan Koutník, Adrian Pryszcz, Miroslav Kaloč \\ VSB - Technical University of Ostrava, Institute of Environmental Technologies, 17. Listopadu 15/2172, Ostrava \\ - Poruba, 708 33, Czech Republic \\ Corresponding authors: e-mail: barbora.grycova@vsb.cz;ivan.koutnik@vsb.cz; adrian.pryszcz@vsb.cz; miroslav.kaloc@vsb.cz
}

\begin{abstract}
The food industry produces large amounts of solid and also liquid wastes. Different waste materials and their mixtures were pyrolysed in the laboratory pyrolysis unit to a final temperature of $800^{\circ} \mathrm{C}$ with a 10 minute delay at the final temperature. After the pyrolysis process of the selected wastes a mass balance of the resulting products, off-line analysis of the pyrolysis gas and evaluation of solid and liquid products were carried out. The highest concentration of methane, hydrogen and carbon monoxide were analyzed during the 4th gas sampling at a temperature of approx. $720-780^{\circ} \mathrm{C}$. The concentration of hydrogen was measured in the range from 22 to $40 \mathrm{vol} . \%$. The resulting iodine numbers of samples CHFO, DS, DSFW reach values that indicate the possibility of using them to produce the so-called "disposable sorbents" in wastewater treatment. The WC condensate can be directed to further processing and upgrading for energy use.
\end{abstract}

Keywords: pyrolysis; gas chromatography; food waste.

\section{INTRODUCTION}

A wide range of waste is produced in agriculture and also in the food industry. These biodegradable wastes are an important group of wastes that threaten the environment in the case of landfilling. Directive No. 1999/31/ EC on the landfilling of waste ${ }^{1}$ requires the Member States of the European Union to reduce the amount of biodegradable waste deposited in landfills until 2010 to 75 wt.\%, until 2013 to $50 \mathrm{wt} . \%$, and until 2020 to 35 wt.\% of the weight of this type of waste generated in the year 1995.

Wastes from the food production are still mostly disposed of by landfilling, only a small part is used for a feed purposes or for the production of biogas ${ }^{2}$ and compost ${ }^{3}$. This waste has long been regarded only as a material for liquidation, and not as a potential high-quality secondary raw material. Disposal or rational use of food wastes represents today a major challenge in terms of environmental protection, but also from an economic perspective. Energy utilization of waste is a progressive method, which provides many advantages ${ }^{4}$. In recent years, due to effort to use renewable energy instead of fossil fuels, new technologies of pyrolysis have been developed, especially for thermal processing of biomass ${ }^{5}$. Thermal methods are promising technologies that allow transforming certain types of wastes to quality fuel or valuable chemical raw materials.

Prerequisite for their successful application is the appropriate choice of input materials and setting of optimal process conditions ${ }^{6}$. For these reasons, suitability or unsuitability of selected types of waste and their mixtures for the pyrolysis process was verified by laboratory experiments with subsequent assessment of the quantity and quality of the individual products of pyrolysis. Pyrolysis (carbonization) belongs together with gasification and combustion to the group of thermochemical processes. It is based on the thermal decomposition of organic materials in the absence of oxidizing media (air, carbon dioxide, water vapor). The possibility of using food wastes through thermal reduction methods is presented in the paper ${ }^{7}$, the authors focused mainly on the quantity and quality of the process gas. Pyrolysis of food waste with respect to the production of bio-oil is also the subject of the papers ${ }^{8,9}$. Microwave pyrolysis with catalysts is a feasible method to handle food wa$\mathrm{ste}^{\mathbf{1 0}}$. In this work ${ }^{\mathbf{1 1}}$ catalytic cracking of biomass waste oil fractions separated from food waste leachate using microporous catalysts is presented.

\section{MATERIAL AND METHODS}

For the experimental part the following samples of waste were chosen:

- $\mathrm{CH}$ - cocoa husks (OpaviaLu, Ltd.),

- CHFO - 90 wt. $\%$ cocoa husks +10 wt. $\%$ waste frying oil from restaurant appliances (OpaviaLu, Ltd.), - DS - dust from the silo from sunflower seeds (STZ, Inc. Olomouc),

- DSFW - 90 wt. $\%$ dust silo +10 wt. $\%$ waste fatty water (STZ, Inc. Olomouc),

- WC - waste cellulose from the production of edible oils (STZ, Inc. Olomouc),

- WCFW - 90 wt.\% waste cellulose + 10 wt. $\%$ waste fatty water (STZ, Inc. Olomouc).

The above mentioned types of wastes are generated in the amount of 80 to 100 tons per month. Most of these wastes are disposed of by landfilling. Selected types of wastes had to be modified before the experiment (granulometry). The knife mill was used to adjust the required size of $8 \times 8 \mathrm{~mm}$. The food industry is producing large amounts of solid and also liquid wastes. Mixtures of liquid waste with a suitable type of solid waste were created in order to compare the effectiveness of thermal treatment of the wastes and their mixtures. For the samples $\mathrm{CH}$, DS and WC proximate and ultimate analysis were carried out (see Table 1). To determine the moisture, the volatile matter and the ash the standards ČSN 44 1377, ČSN ISO 562 and ČSN ISO 1171 were used. For determination of HHV by the bomb calorimetric method the standard ČSN ISO 1928 was used.

The liquid samples, i.e. waste frying oil and waste fatty water, were submitted to the following examinations (see Table 2). 
Table 1. Proximate and ultimate analysis (converted to the original sample)

\begin{tabular}{|l|c|c|c|c|c|c|c|c|c|c|}
\hline Sample & $\begin{array}{c}\text { Moisture } \\
\text { content } \\
{[\text { wt.\%] }}\end{array}$ & $\begin{array}{c}\text { Ash } \\
{[\text { wt.\%] }}\end{array}$ & $\begin{array}{c}\text { Total } \\
\text { combustible } \\
{[\text { wt.\%] }}\end{array}$ & $\begin{array}{c}\mathrm{C} \\
{[\mathrm{wt} . \%]}\end{array}$ & $\begin{array}{c}\mathrm{H} \\
{[\mathrm{wt} . \%]}\end{array}$ & $\begin{array}{c}\mathrm{N} \\
{[\mathrm{wt} . \%]}\end{array}$ & $\begin{array}{c}\mathrm{S} \\
{[\mathrm{wt} . \%]}\end{array}$ & $\begin{array}{c}\mathrm{O} \\
{[\mathrm{wt} . \%]}\end{array}$ & $\begin{array}{c}\mathrm{HHV} \\
{\left[\mathrm{MJ} \cdot \mathrm{kg}^{-1}\right]}\end{array}$ & $\begin{array}{c}\mathrm{LHV} \\
{\left[\mathrm{MJ} \cdot \mathrm{kg}^{-1}\right]}\end{array}$ \\
\hline CH & 8.5 & 6.3 & 85.2 & 46.2 & 6.3 & 2.7 & $<0.2$ & 30.0 & 19.3 & 18.5 \\
\hline DS & 13.4 & 6.4 & 80.2 & 35.3 & 5.2 & 1.9 & $<0.2$ & 37.8 & 16.2 & 14.9 \\
\hline WC & 5.1 & 0.1 & 94.8 & 45.8 & 6.5 & 0.2 & $<0.2$ & 42.3 & 24.2 & 22.7 \\
\hline
\end{tabular}

Table 2. Parameters set of waste frying oil and waste fatty water

\begin{tabular}{|c|c|c|c|}
\hline Parameter & Standards & Waste frying oil & Waste fatty water \\
\hline \multirow{2}{*}{$\begin{array}{l}\text { Kinematic viscosity } \\
{\left[\mathrm{mm}^{2} \cdot \mathrm{s}^{-1}\right]}\end{array}$} & \multirow{2}{*}{ ASTM 445-06 } & $110.63\left[20^{\circ} \mathrm{C}\right]$ & $73.25\left[20^{\circ} \mathrm{C}\right]$ \\
\hline & & $4.86\left[150^{\circ} \mathrm{C}\right]$ & $3.85\left[150^{\circ} \mathrm{C}\right]$ \\
\hline Point of ignition $\left[{ }^{\circ} \mathrm{C}\right]$ & ČSN 656244 & over 300 & 273 \\
\hline Residual coke [\%] & ISO 6998/84 & 0.58 & 0.43 \\
\hline Arsenic $\left[\mathrm{mg} \cdot \mathrm{kg}^{-1} \mathrm{DM}\right]$ & ČSN EN ISO 15586 & $<0.50$ & 0.61 \\
\hline Cadmium $\left[\mathrm{mg} \cdot \mathrm{kg}^{-1} \mathrm{DM}\right]$ & ČSN EN ISO 5961 & 0.10 & 0.17 \\
\hline Chromium $\left[\mathrm{mg} \cdot \mathrm{kg}^{-1} \mathrm{DM}\right]$ & ČSN EN 1233 & $<2.50$ & $<2.50$ \\
\hline Copper $\left[\mathrm{mg} \cdot \mathrm{kg}^{-1} \mathrm{DM}\right]$ & ČSN ISO 8288 & $<2.50$ & $<2.50$ \\
\hline Mercury $\left[\mathrm{mg} \cdot \mathrm{kg}_{\mathrm{DM}}^{-1}\right]$ & TNV 757440 & 0.004 & 0.006 \\
\hline Nickel $\left[\mathrm{mg} \cdot \mathrm{kg}^{-1}{ }_{\mathrm{DM}}\right]$ & ČSN ISO 8288 & $<2.50$ & $<2.50$ \\
\hline Lead $\left[\mathrm{mg} \cdot \mathrm{kg}^{-1} \mathrm{DM}\right]$ & ČSN ISO 8288 & $<2.50$ & $<2.50$ \\
\hline Zinc $\left[\mathrm{mg} \cdot \mathrm{kg}^{-1} \mathrm{DM}\right]$ & ČSN ISO 8288 & $<2.50$ & 4.25 \\
\hline TOC [\% & ČSN EN 13370 & n.d. & 79.60 \\
\hline Total dry matter [\%] & ČSN EN 12879 & 99.90 & 99.70 \\
\hline Combustibles [\% $\left.\%_{\mathrm{DM}}\right]$ & ČSN EN 12879 & 99.80 & $>99.90$ \\
\hline Total sulfur $\left[\mathrm{g} \cdot \mathrm{kg}^{-1} \mathrm{DM}\right]$ & SOP 94 (method) & 0.17 & 0.41 \\
\hline Ammoniacal nitrogen $\left[\mathrm{mg} \cdot \mathrm{kg}^{-1} \mathrm{DM}\right]$ & SOP 65 (method) & $<10.00$ & 1.73 \\
\hline Total nitrogen [\% DM] & SOP 61 (method) & $<0.01$ & 0.02 \\
\hline
\end{tabular}

\section{Experimental device}

Laboratory apparatus assembled for the purpose of experiments is shown in Figure 1. A sample with an appropriate mass $(80 \mathrm{~g})$ was placed into the prepared retort. The retort was gas-tightly closed, inserted into the tube furnace and connected to the rest of the components of the device, so that the condensate was captured in a flask and the production of process gas was measured afterwards. The nitrogen was used as an inert medium for the pyrolysis experiments. The flask was cooled down by ice with sodium chloride to achieve a lower temperature (around $-10^{\circ} \mathrm{C}$ ). The heating of the retort was set up to $15 \mathrm{~K}$ per minute to the final temperature of $800^{\circ} \mathrm{C}$. The pyrolysis gas was cooled in a water cooler and cleaned in a wash tank with acetone water. Afterwards the pyrolysis gas samples were taken discontinuously at different processing temperatures into a glass sample containers. The selected combustible components were analyzed by gas chromatography (methane, ethylene, propane, hydrogen, carbon monoxide and carbon dioxide). The reproducibility of the results was verified.

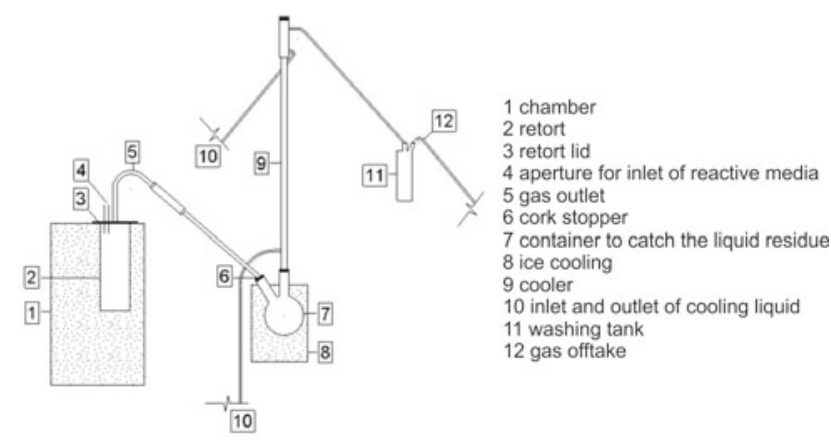

Figure 1. Pyrolysis apparatus

\section{RESULTS AND DISCUSSION}

Mass balance of the pyrolysis tests was determined by weighing the particular products from the pyrolysis (solid residue, liquid residue). The amount of resulting gas was calculated up to $100 \%$. Distribution of the individual products is primarily based on the reaction temperature. The most important properties are the elemental composition and the structure of the input material. The increase of liquid residue of WC sample is probably caused by higher content of oxygen in original material. Materials with a higher content of oxygen yield oxygenated products during the pyrolysis more. The addition of waste frying oil to the sample $\mathrm{CH}$ caused an increase of the liquid phase with a concomitant decrease of the solid phase. By adding waste fatty water to DS and WC we can observe the increase of condensate by about 5 wt. $\%$.

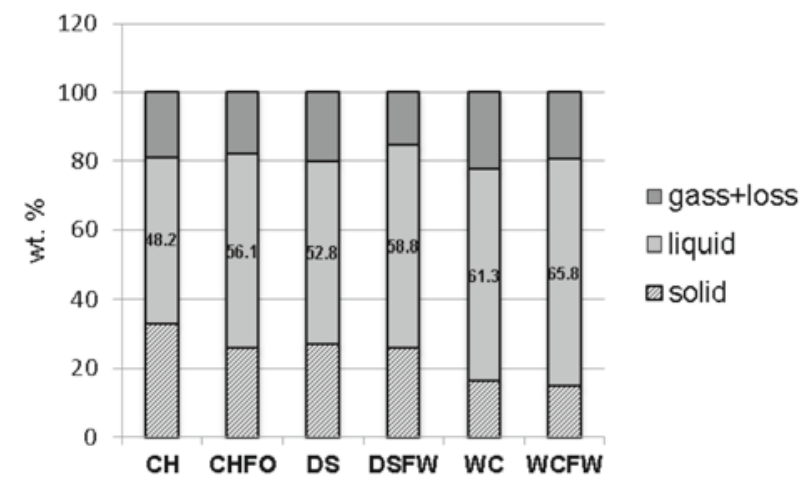

Figure 2. Mass balance of pyrolysis process

\section{Analysis of gaseous products}

Analysis of the pyrolysis gas was performed with the use of the Agilent 7890A gas chromatograph with flame ionization detector (FID) and thermal conductivity detector (TCD). For separation of gaseous components the GasPro column (length $60 \mathrm{~m}$, inner diameter $0.320 \mathrm{~mm}$ ) 
was used. FID was used to detect methane, ethylene and propane. Hydrogen, carbon monoxide and carbon dioxide were detected by TCD. For dosing the gaseous samples a metering loop was used and the output signal was recorded and processed by the HP ChemStation computer software. Conditions for the chromatographic analysis are shown in Table 3.

Samples of the pyrolysis gas were taken from the moment when the gas started to evolve as well as during the most intense evolution of gas. Based on this principle of gas offtake, the temperatures of gas sampling were different for each gas sample (see Fig. 3). Four samples of gas were taken for each waste; due to very low concentrations the first sample was omitted. The highest concentrations of methane, hydrogen and carbon monoxide were analyzed during the $4^{\text {th }}$ gas sampling at temperature of approx. $720-780^{\circ} \mathrm{C}$, with the exception of samples DS and WC (decrease of carbon monoxide). The addition of frying oil to the sample $\mathrm{CH}$ caused in the 4th sampling the reduction of the hydrogen content by 9 vol.\% with simultaneous increase of the content of methane and carbon monoxide. The lower heating values of gas (4th sampling) of the $\mathrm{CH}$ and $\mathrm{CHFO}$ were almost comparable (CH: $\left.15.7 \mathrm{MJ} \cdot \mathrm{m}^{-3} / \mathrm{CHFO}: 15.6 \mathrm{MJ} \cdot \mathrm{m}^{-3}\right)$. In the case of mixtures with the waste fatty water the lower heating values are following $-4^{\text {th }}$ sampling DS: $13.7 \mathrm{MJ} \cdot \mathrm{m}^{-3} / \mathrm{DSFW}: 15.3 \mathrm{MJ} \cdot \mathrm{m}^{-3}$; WC: $17.0 \mathrm{MJ} \cdot \mathrm{m}^{-3} /$ WCFW: $17.5 \mathrm{MJ} \cdot \mathrm{m}^{-3}$.

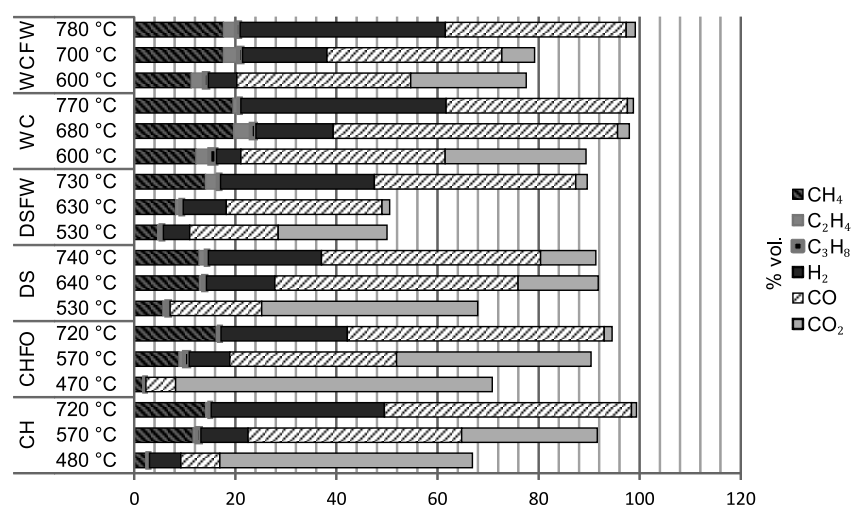

Figure 3. Analysis of gaseous products for the pyrolysed samples

The production of hydrogen is an important parameter, which is discussed in a number of papers on process conditions and thermodynamic efficiency ${ }^{12}, 13,14,15,16$. In the case of the pyrolysis experiments the hydrogen concentration fluctuated in specific stages of the process (4th sampling) in the range from 22 to 40 vol.\%.

\section{Evaluation of solid residues in terms of adsorption properties}

Basic determination of solid residues of pyrolysed samples was done to define the sorption capacity (the iodine adsorption number). To determine the iodine adsorption number I, which provides information about the microporous structure of the solid product, the standard DIN $53582^{17}$ was used. The automatic pycnometer PYCNOMATIC ATC was used to analyze the true density $\mathrm{Q}$ of the solid products (helium was used as a medium). Nowadays a new trend is growing up for production of sorbents from biomass and various kinds of waste materials. These raw materials are available at minimal cost, for example timber, sawdust, pine cones ${ }^{\mathbf{1 8}}$, shelled pistachio nuts ${ }^{19}$, fruit peels ${ }^{20}$, fruit stones ${ }^{21}$, tea leaves $^{22}$, sewage sludge from industrial wastewater treatment plants ${ }^{23}$ and other. The following table shows the results of ultimate and proximate analysis (moisture $\mathrm{W}$, ash A, volatile V), iodine adsorption numbers I and true density @ of samples after pyrolysis.

The iodine numbers of samples CHFO, DS, DSFW reach values that indicate the possibility of using them to produce the so-called "disposable sorbents". These types of sorbents could be used in wastewater treatment (to capture cations of heavy metals or some organic compounds). In the case of the other samples the spatial structure of the original material probably negatively affects the sorption capacity of the resulting solid product. The solid residues of mixed samples have a higher true density. Process of the carbonization in terms of preparation of the adsorbents can be affected in different ways, e.g. the final carbonization temperature, the heating rate, the granulometric composition of raw materials, carbonization under elevated or reduced pressure, etc. Material with a high adsorption capacity can be obtained by activating the carbonized product under conditions where the activating agent (water vapor, $\mathrm{CO}_{2}$, etc.) is reacted with carbon. Material with a high adsorption capacity can be produced also in another way, so that the carbonaceous initial material is carbonized with the addition of the substances restricting the formation of tars (e.g. $\mathrm{ZnCl}_{2}$ or other Lewis acids). The high adsorption capacity of adsorbents is due to a large number of pores

Table 3. Conditions for analysis of gaseous product by means of a gas chromatograph

\begin{tabular}{|c|c|c|c|c|c|}
\hline \multicolumn{2}{|l|}{ Column setting } & \multicolumn{2}{|l|}{ FID detector setting } & \multicolumn{2}{|l|}{ TCD detector setting } \\
\hline Temperature $\left[{ }^{\circ} \mathrm{C}\right]$ & 200 & \multirow[t]{2}{*}{ Temperature $\left[{ }^{\circ} \mathrm{C}\right]$} & \multirow[t]{2}{*}{300} & \multirow[t]{2}{*}{ Temperature $\left[{ }^{\circ} \mathrm{C}\right]$} & \multirow[t]{2}{*}{260} \\
\hline Pressure [Psi] & 15.7 & & & & \\
\hline Flow rate $\left[\mathrm{ml} \cdot \mathrm{min}^{-1}\right]$ & 3.3 & Flow rate of $\mathrm{H}_{2}\left[\mathrm{ml} \cdot \mathrm{min}^{-1}\right]$ & 30 & \multirow[t]{2}{*}{ Flow rate of $\mathrm{H}_{2}\left[\mathrm{ml} \cdot \mathrm{min}^{-1}\right]$} & \multirow[t]{2}{*}{2} \\
\hline \multirow[t]{2}{*}{ Split ratio } & \multirow[t]{2}{*}{$10: 1$} & Airflow $\left[\mathrm{ml} \cdot \mathrm{min}^{-1}\right]$ & 400 & & \\
\hline & & Flow rate of $\mathrm{He}\left[\mathrm{ml} \cdot \mathrm{min}^{-1}\right]$ & 25 & Flow rate of $\mathrm{He}\left[\mathrm{ml} \cdot \mathrm{min}^{-1}\right]$ & 5 \\
\hline
\end{tabular}

Table 4. Proximate and ultimate analysis, iodine adsorption number and true density

\begin{tabular}{|c|c|c|c|c|c|c|c|c|c|}
\hline Sample & $\begin{array}{c}\mathrm{C} \\
{[\mathrm{wt} . \%]}\end{array}$ & $\begin{array}{c}\mathrm{H} \\
{[w t . \%]}\end{array}$ & $\begin{array}{c}\mathrm{N} \\
{[\mathrm{wt} . \%]}\end{array}$ & $\begin{array}{c}\mathrm{HHV} \\
{\left[\mathrm{MJ} \cdot \mathrm{kg}^{-1}\right]}\end{array}$ & $\begin{array}{c}\mathrm{W}^{\mathrm{a}} \\
{[\mathrm{wt} . \%]}\end{array}$ & $\begin{array}{c}\mathrm{A}^{\mathrm{d}} \\
{[\mathrm{wt} \% \text { \%] }}\end{array}$ & $\begin{array}{c}\mathrm{V}^{\mathrm{d}} \\
\text { [wt.\%] }\end{array}$ & $\begin{array}{c}\mathrm{I} \\
{\left[\mathrm{mg} \cdot \mathrm{g}^{-1}\right]}\end{array}$ & {$\left[\begin{array}{c}\rho \\
{\left[\mathrm{g} \cdot \mathrm{cm}^{-3}\right]}\end{array}\right.$} \\
\hline $\mathrm{CH}$ & 72.0 & 0.9 & 2.9 & 24.1 & 3.3 & 23.6 & 11.4 & 107 & 1.22 \\
\hline CHFO & 66.7 & 1.2 & 2.3 & 21.7 & 6.6 & 21.4 & 17.0 & 199 & 1.39 \\
\hline DS & 71.5 & 1.3 & 2.2 & 22.7 & 6.1 & 24.2 & 18.4 & 217 & 1.57 \\
\hline DSFW & 62.4 & 1.0 & 2.1 & 22.8 & 5.7 & 24.3 & 16.4 & 189 & 1.65 \\
\hline WC & 93.9 & 0.9 & 0.3 & 33.5 & 3.2 & 5.2 & 7.1 & 57 & 1.28 \\
\hline WCFW & 89.7 & 0.8 & 0.3 & 31.5 & 4.6 & 5.1 & 8.6 & 68 & 1.30 \\
\hline
\end{tabular}


of different sizes. Their application is primarily in the so-called cleaning technologies ${ }^{24}$.

\section{Evaluation of condensates}

Currently, the pyrolysis condensate (a very complex mixture of oxygenated hydrocarbons with an appreciable proportion of water) has attracted considerable interest due to its several applications in industry. Although it has been proven to be a promising alternative to petroleum fuels, it also has a potential for use in producing valueadded chemicals. On the base of the mass balance after the pyrolysis experiments the condensate of WC sample was analyzed. Analyses were performed externally in the laboratory Deza, Inc. The content of carbon, hydrogen, nitrogen and sulphur was determined with the use of the unit NA 1500 (Fisons Instruments, Milan), operated in the CHNS mode, calibrated according to standard commercial phenanthrene in compliance with Internal Regulation No 312/1. Water content was determined by the Karl-Fischer method (ČSN ISO 760).

The heating values of the organic phase of the WC condensate from pyrolysis indicate the possibility of its further use for energy recovery. The above mentioned sample was also subjected to the determination of organic ingredients provided by $\mathrm{GC}-\mathrm{MS}$ gas chromatograph $\mathrm{HP}$ 6890 (HP 5973 MSD) with temperature programme of $60-280^{\circ} \mathrm{C}$ (temperatures of the mass spectrometer: the ion source $230^{\circ} \mathrm{C}$, the quadrupole $150^{\circ} \mathrm{C}$ ). For separation the HP - 5MS inert column (length $60 \mathrm{~m}$, inner diameter $0.320 \mathrm{~mm}$ ) was used. The split ratios were 50:1, 20:1, and 10:1. Chloroform was used for sample preparation. The results are shown in Table 6 .

The results demonstrated that the pyrolysis liquid produced during the process is a multicomponent mixture wherein the concentration of the most representative components does not exceed $10 \%$. For mixtures of this type it is quite complicated to find an application with the exception of mixtures containing the component whose value could compensate for the cost of separation. The substances used in the flavours industry are among the most represented components of the given mixture (capronaldehyde, valeric acid, caprylic acid, caproic acid). Possible utilization could be based on these components as seen in the table below.

\section{CONCLUSION}

The resulting pyrolysis products (solid product, condensate and gas) are dependent on the composition of the treated waste and process conditions. Process conditions can be variously modified with respect to quantity and quality of the products that we want primarily to obtain. The advantage of thermal reduction processes is the emergence of process gas containing combustible components such as methane, hydrogen, and carbon monoxide which can be used for energy production. There is also potential for energy use of condensate (the low heating value of $\mathrm{WC}$ condensate is $33.1 \mathrm{MJ} \cdot \mathrm{kg}^{-1}$ ). The resulting iodine numbers of samples CHFO, DS, DSFW reach values that indicate the possibility of using them to produce the so-called "disposable sorbents" in wastewater treatment (to capture cations of heavy metals or some organic compounds). For a comprehensive assessment of their suitability it would be necessary to provide additional characterization of their basic parameters, such as surface area, pore volume, pore size distribution, bulk and apparent density. By adding waste frying oil to the $\mathrm{CH}$ sample, an increase of the value of the iodine adsorption number from initial $107 \mathrm{mg} \cdot \mathrm{g}^{-1}$ to $199 \mathrm{mg} \cdot \mathrm{g}^{-1}$ has been achieved. By adding waste fatty water to the DS sample, an increase of concentration of hydrogen by 8 vol. $\%$ has been achieved. The topic

Table 5. Proximate and ultimate analysis of WC condensate

\begin{tabular}{|c|c|c|c|c|c|c|c|}
\hline Sample & $\begin{array}{l}\mathrm{C} \\
\text { [wt.\%] }\end{array}$ & $\begin{array}{l}\mathrm{H} \\
\text { [wt.\%] }\end{array}$ & $\begin{array}{l}\mathrm{N} \\
{[w t . \%]}\end{array}$ & $\begin{array}{l}\text { S } \\
\text { [wt.\%] }\end{array}$ & $\begin{array}{l}\text { W } \\
\text { [wt.\%] }\end{array}$ & $\begin{array}{l}\mathrm{HHV} \\
\left.\mathrm{MJ} \cdot \mathrm{kg}^{-1}\right]\end{array}$ & $\begin{array}{l}\text { LHV } \\
{\left[\mathrm{MJ} \cdot \mathrm{kg}^{-1}\right]}\end{array}$ \\
\hline WC & 74.2 & 10.9 & 0.8 & $<0.2$ & 43.6 & 36.6 & 33.1 \\
\hline
\end{tabular}

Table 6. Determination of organic components

\begin{tabular}{|c|c|c|c|}
\hline Identified component & [rel.\%] & Identified component & [rel.\%] \\
\hline Toluene & 0.92 & 3,4-dimethylphenol & 1.32 \\
\hline Capronaldehyde & 8.15 & 4-methylguaiacol & 1.42 \\
\hline Vinylcyclohexene & 0.78 & Naphthalene & 2.08 \\
\hline Ethylbenzene & 0.10 & Pelargonic acid & 1.18 \\
\hline$p+m-x y l e n e$ & 0.36 & 2,4,5-trimethylphenol & 0.69 \\
\hline 2-heptanone & 1.50 & 4-ethylguaiacol & 2.00 \\
\hline Methylcapronat & 1.07 & 2-methylnaphthalene & 1.64 \\
\hline Valeric acid & 8.60 & 1-methylnaphthalene & 0.90 \\
\hline Phenol & 1.80 & Phenylcyclohexene & 0.60 \\
\hline Benzonitrile & 1.00 & 1-tetradecene & 0.48 \\
\hline 1,2,4-trimethylbenzene & 0.90 & Tetradecane & 0.33 \\
\hline Methylenathat & 0.20 & Biphenyl & 0.74 \\
\hline 1,2,3-trimethylbenzene & 0.40 & 2-ethylnaphthalene & 0.39 \\
\hline 2-methylphenol & 1.10 & 1,3-dimethylnaphthalene & 0.46 \\
\hline 3+4-methylphenol & 0.92 & 1-dodecanol & 0.80 \\
\hline 1-ethyl-2,3-dimethylbenzene & 0.80 & Pentadecane & 0.91 \\
\hline Guaiacol & 1.43 & Hexadecane & 0.31 \\
\hline Pelargonaldehyde & 0.70 & 1-pentadecanol & 0.46 \\
\hline Caprylic acid & 3.60 & Heptadecane & 0.84 \\
\hline 3,5-dimethylphenol & 1.10 & Methyl palmitate & 0.85 \\
\hline
\end{tabular}


presented in this paper is wide and offers a variety of pyrolysis process modifications of selected types of waste.

\section{ACKNOWLEDGEMENTS}

This paper has been elaborated in the framework of the project New creative teams in priorities of scientific research, reg. no. CZ.1.07/2.3.00/30.0055, supported by Operational Programme Education for Competitiveness and co-financed by the European Social Fund and the state budget of the Czech Republic.

\section{LITERATURE CITED}

1. Council Directive 1999/31/EC of 26 April 1999 on the landfill of waste. Official Journal L 182, 16/07/1999, 1-19.

2. Rusín, J., Chamrádová, K., Obroučka, K. \& Kuča, R. (2012). Methane production during laboratory-scale co-digestion of cattle slurry with 10 wt. \% of various biowastes. Pol. J.Chem. Technol. 14(1), 14-20. DOI: 10.2478/v10026-012-0053-x.

3. Tronina, P. \& Bubel, F. (2008). Food industry waste composting in a rotational reactor. Pol. J.Chem. Technol. 10(2), 37-42. DOI: 10.2478/v10026-008-0026-2.

4. Obroučka, K. (2001). Thermal removal and energetic use of wastes. 1. ed. script. Ostrava: VŠB-TUO.

5. Jílková, L., Ciahotný, K. \& Černý, R. (2012). Technologie pro pyrolýzu paliv a odpadů. Paliva 4(3), 74-80.

6. Holcová, P. \& Kaloč, M. (2006). Hodnocení vlastností pyrolýzních produktů z odpadní biomasy. In Úprava nerostných surovin (pp. 63-71). VŠB TU Ostrava.

7. Ahmed, I.I. \& Gupta, A.K. (2010). Pyrolysis and gasification of food waste. Syngas characteristics and char gasification kinetics. Appl. Ener. 87(1), 101-108. DOI: 10.1016/j. apenergy.2009.08.032.

8. Puangubol, S., Utistham, T. \& Wetwatana, U. (2011). Production of bio-oil by hydrothermal pyrolysis of food waste over ceria catalyst. Curr. Opin. Biotech. 22(1), 49. DOI: 10.1016/j. copbio.2011.05.128.

9. Önal, Eylem P., Uzun, Basak B., Putun \& Ayse, E. (2011). Steam pyrolysis of an industrial waste for bio-oil production. Fuel Process. Technol. 92(5), 879-885. DOI: 10.1016/j. fuproc.2010.12.006.

10. Haili, L., Xiaogian, M., Longjun, L., Zhifeng, H., Pingsheng, G. \& Juhui, J. (2014). The catalytic pyrolysis of food waste by microwave heating. Biores. Technol. 166, 45-50. DOI: 10.1016/j. biortech.2014.05.020.

11. Hyeon, S.H., Sang, G.K., Kwang-Eun, J. \& Jong-Ki, J. (2011). Catalytic upgrading of oil fractions separated from food waste leachate. Biores. Technol. 104(4), 3952-3957. DOI: 10.1016/j.biortech.2010.11.099.

12. Kalinci, I., Hepbasli, A. \& Dincer, I. (2009). Biomass-based hydrogen production: A review and analysis. Inter. J. Hydro. Ener. 34(21), 8799-8817. DOI: 10.1016/j.ijhydene.2009.08.078. 13. Liu, H., Zhang, Q., Hu, H., LI, A. \& Yao, H. (2014). Influence of residual moisture on deep dewatered sludge pyrolysis. Inter. J. Hydro. Ener. 39(3), 1253-1261. DOI: 10.1016/j. ijhydene.2013.10.050.

14. Ma, Z., Zhang, S.P., Xie, D.Y. \& Yan, Y.J. (2014). A novel integrated process for hydrogen production from biomass. Inter. J. Hydro. Ener. 39(3), 1274-1279. DOI: 10.1016/j. ijhydene.2013.10.146.

15. Kim, S.C., Lim, M.S. \& Chun, Y.N. (2013). Hydrogenrich gas production from a biomass pyrolysis gas by using a plasmatron. Inter. J. Hydro. Ener. 38(34), 14458-14466. DOI: 10.1016/j.ijhydene.2013.09.004.

16. Bičáková, O. \& Straka, P. (2012). Production of hydrogen from renewable resources and its effectiveness. Inter. J. Hydro. Ener. 37(16), 11563-11578. DOI: 10.1016/j.ijhydene.2012.05.047.
17. DIN 53582. (1983). Prüfung von Rußen; Bestimmung der Jodadsorptionszahl (Testing of carbon black; determination of iodine adsorption number).

18. Momčilović, M., Purenović, M., Bojić, A., Zarubica, A. \& Rendelović, M. (2011). Removal of lead (II) ions from aqueous solutions by adsorption onto pine cone activated carbon. Desalination 276(1-3), 53-59. DOI: 10.1016/j.desal.2011.03.013. 19. Foo, K.Y. \& Hameed, B.H. (2011). Preparation and characterization of activated carbon from pistachio nut shells via microwave - induced chemical activation. Biomass and Bioenergy 35(7), 3257-3261. DOI: 10.1016/j.biombioe.2011.04.023.

20. Foo, K.Y. \& Hameed, B.H. (2011). Microwave assisted preparation of activated carbon from pomelo skin for the removal of anionic and cationic dyes. Chem. Engineer. J. 173(2), 385-390. DOI: 10.1016/j.cej.2011.07.073.

21. Mouni, L., Merabet, D., Bouzaza, A. \& Belkhiri, L. (2011). Adsorption of $\mathrm{Pb}$ (II) from aquaeous solutions using activated carbon developer from apricot stone. Desalination 276(1-3), 148-153. DOI: 10.1016/j.desal.2011.03.038.

22. Kazmi, M., Saleemi, A.R., Feroze, N., Yaqoob, A. \& Ahmad, S.W. (2013). Removal of phenol from wastewater using activated waste tea leaves. Pol. J. Chem. Technol. 15 (2), 1-6. DOI: $10.2478 /$ pjet-2013-0016.

23. Otero, M., Rozada, F., Calvo, L.F., Garcia, A.I. \& Moran, A. (2003). Kinetic and equilibrium modelling of the methylene blue removal from solution by adsorbent materials produced from sewage sludges. Biochem. Eng. J. 15(1), 59-68. DOI: 10.1016/S1369-703X(02)00177-8.

24. Siyal, A.N., Memon, S.Q., Amanullah, M., Pirzada, T., Parveen, S. \& Sodho, N.A. (2013). Multi-variant sorption optimization for the uptake of $\mathrm{Pb}(\mathrm{II})$ ions by Jamun Seed Waste. Pol. J. Chem. Technol. 15 (1), 15-21. DOI: 10.2478/ pjct-2013-0004. 